\title{
BŪSIMOJO SPECIALISTO IDENTIFIKACIJA SU STUDENTO VAIDMENIU KAIP PROFESINĖS KARJEROS SĄLYGA
}

\author{
Diana Karanauskienė, Laimutė Kardelienė, Kęstutis Kardelis \\ Lietuvos kūno kultūros akademija, Kaunas, Lietuva
}

\begin{abstract}
Diana Karanauskienė. Socialinių mokslų daktarè. Lietuvos kūno kultūros akademijos Kalbų katedros lektorė, Kūno kultūros ir sporto socialinių problemų laboratorijos jaunesnioji mokslo darbuotoja. Mokslinių tyrimų kryptys: studentų identitetas ir identifikacijos aukštojoje universitetinèje mokykloje; kokybinių tyrimų metodologija.
\end{abstract}

\section{SANTRAUKA}

Tyrimu siekta išsiaiškinti, kaip Lietuvos kūno kultūros akademijos studentai konstruoja savo studentiška identiteta, t. y. kaip jie identifikuojasi su studento socialiniu vaidmeniu. Buvo klausiama, kokia prasmę studentai suteikia šiam vaidmeniui, kuo jis jiems reikšmingas ir kuo ipareigoja. Išsami studentiško identiteto analize leistu prognozuoti, kaip studentai nusiteikę mokytis, siekti mokslo žiniu. Ieškant atsakymo ì šiuos klausimus, tyrimo objektu pasirinkta studijuojančiuju identifikacija su studento vaidmeniu aukštojoje universitetineje mokykloje, o tyrimo tikslu siekta atskleisti identifikacijos su šiuo vaidmeniu raiška.

Tyrimo metu taikytas pusiau struktūrizuotas interviu, todèl sudarytas klausimynas, kurio struktūra atitinka teoriškai pagristus identifikacijos su vaidmeniu bruožus. Tiriamuju imtis - tikslinè, arba teoriné. Tiriamieji parinkti savanoriškumo principu. Svarbiausias tiriamiesiems taikomas kriterijus — būti išgyvenus fenomena, domètis jo prigimtimi ir prasmèmis. Imties tūri, kokybinio tyrimo metu taikant interviu metoda, sudare 54 Sporto edukologijos bei Sporto technologiju ir turizmo fakultetu I-IV kursu studentai, parinkti pagal anksčiau nurodytus kriterijus.

Studentu vaidmens identifikacija rodo, kaip jie, kaip studentai, suvokia savo užimama socialinę pozicija aukštojoje mokykloje. Visi vaidmens identifikacijos požymiai gali būti sèkmingu studiju, savarankiško ir atsakingo darbo prielaidomis. Tyrimas taip pat atskleide, kad studentai savo vaidmeni suvokia ne tik kaip susijusi su mokymusi, darbu, bet ir su studentavimu — dalyvavimu ¿̇vairiuose studentiškuose kultūriniuose ir sportiniuose renginiuose. Tyrimo rezultatai leidžia hipotetiškai teigti, kad akademinio jaunimo sèkminga identifikacija su studento vaidmeniu lemia tokie mokymosi aplinkos komponentai: 1) komunikacinis, ypač bendradarbiavimas su akademinès bendruomenès nariais, išgyvenant teigiamas emocijas; 2) pragmatinis, ypač studiju organizavimas, derinant studentu poreikius ir studiju programos tikslu realizavima; 3) vertybinis, išskiriant dokumentu apie aukštaji moksla ir aukštaja universitetinę mokykla analizę, igalinant studijuojantiji vertinti savo, kaip studento, teises ir pareigas, atskleidžiant jam studento, kaip partnerio, privalumus. Išvardytieji akademinio jaunimo identifikacijos su studento vaidmeniu aspektai lemia ir karjeros ypatumus, ir profesini ìvaizdi, sąlygojantị kūno kultūros ir sporto specialisto prestižq visuomeneje.

Raktažoď̌iai: socialine identifikacija, studento socialinis vaidmuo, vaidmens identifikacija, aukštoji mokykla.

\section{IVADAS}

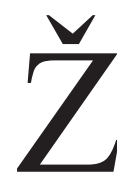
inių visuomenè neimanoma be efektyviai dirbančių kvalifikuotų pedagogų, taigi ir be moksleivių sveikatą ugdančių kūno kultūros mokytojų, sporto šakos trenerių. Kadangi šios srities specialistus rengia aukštosios universitetinès mokyklos, tai mokslininkai atlieka fundamentaliuosius ir taikomuosius tyrimus, siekdami atskleisti kūno kultūros mokytojų ir sporto šakos treneriu profesinio identifikavimosi ypatumus. Studijų pradžioje studentams nurodoma, kuria kryptimi tikslinga projektuoti savo studijas (Malinauskas, 2004; Kardelienè, Kardelis, 2006), aptariama, kokių kompetencijų ugdymosi iš jų laukiama (Kardelienè ir kt., 2005), tiriama, kas lemia studijų efektyvumą (Chen, 2003; Kardelienè, 2005; Karanauskienė, 2006). Mokslininkai tiria veiksnius, kurie lemia kūno kultūros mokytojo ir sporto specialisto profesinę karjerą studiju metais.

Studijuojančio asmens akademiniams pasiekimams turi itakos tai, kaip jis suvokia savo, kaip studento, vaidmeni (Osborne, 1997; Voelkl, 1997). Be to, šis suvokimas lemia ir asmens socialini identitetą (Purdie, 2003), nes akademinè identifikacija yra viena iš socialinio identiteto apraišku aukštojoje mokykloje. 
Būdamas socialinio sluoksnio ar grupès nariu, asmuo užima joje tam tikrą padètị ir atlieka tam tikrą vaidmeni, kuris jam tampa prasmingas pagal tai, ko kiti žmonès iš jo tikisi. Todèl socialinio identiteto pagrindas - tai asmens atliekamo socialinio vaidmens ittraukimas į savivoką (Burke, 1991). Šiuo požiūriu studento vaidmuo - tam tikra elgsena, kurią lemia sąmoningas, refleksyvus, kūrybiško savojo vaidmens suvokimas, be to, tai ir socialinè situacija, ir studento socialinè pozicija (Burke, Tully, 1977), todèl asmenys, patekę i naują socialinę grupę, t. y. aukštają mokyklą, ir igavę tam tikrą statusą, pradeda atlikti su tuo vaidmeniu susijusius veiksmus. Vadinasi, nuo identifikacijos su studijomis priklausys ir asmens akademinè sẻkmè, ir įsidarbinimo galimybės bei konkurencingumas darbo rinkoje.

Mokslinès literatūros šaltiniuose samprotaujama apie sąsajas tarp studentų identifikacijos su ugdymo institucija ir studiju pasiekimais (Marx et al., 1999; Steele, 2003), rašoma apie empiriškai tirta studentu akademini (Osborne, 1997; Karanauskienè, Kardelis, 2005) bei tautini (Antinienè, 2002; Dolby, 2004) identitetus. Akcentuotina, kad retai aptinkama darbų, aprašančių studentų identifikaciją aukštojoje mokykloje, ypač rengiant kūno kultūros ir sporto specialistus, todèl neaišku, kaip šie specialistai kuria studento identitetą, kaip jie identifikuojasi su studento vaidmeniu, kuo šis vaidmuo jiems reikšmingas ir kam įpareigoja. Ieškant atsakymo i šiuos klausimus, suplanuotas tyrimas, kurio objektu pasirinkta studijuojančiujuc identifikacija su studento vaidmeniu aukštojoje universitetinèje mokykloje, o tyrimo tikslu siekta atskleisti identifikacijos su šiuo vaidmeniu raišką.

\section{TYRIMO METODIKA}

Tyrimo metodas. Tyrimo metu taikytas pusiau struktūrizuotas interviu, todèl sudarytas klausimynas, kurio struktūra atitinka teoriškai pagrịstus identifikacijos su vaidmeniu bruožus. Bandomojo tyrimo metu pasirinkus nestruktūrizuotą interviu pastebèta, kad tiriamieji, savanoriškai sutikę dalyvauti apklausoje, nepamini visų ar daugelio bruožų, kurie išskirti atliekant kitus socialinès identifikacijos tyrimus. Tačiau griežtai struktūrizuotas interviu, taikytas per bandomaji tyrimą, isprausdavo studentus i tyrejo pateiktų atsakymo variantų rẻmus, neskatindavo jų mąstyti. Tad pusiau struktūrizuotas interviu pasirode kaip optimalus bei priimtinas apklausos metodas, garantuojantis aktyvų dialogą tarp tyrejo ir tiriamujų, padedantis sukurti pasitikejjimo aplinką, leidžiantis tyrejui patikrinti ir suvienodinti apklausos dalyvių pateiktų formuluočiu prasmę.

Tyrimo dalyvių parinkimas ir tiriamoji imtis. Vienas svarbiausių kokybinio tyrimo bruožu yra tikslinè, arba teorinè, tiriamujų imtis (Strauss, Corbin, 1998), kurios nesąlygoja statistinès procedūros siekiant tyrimo rezultatus apibendrinti kaip didesnès populiacijos. Mat i imti parenkami tik tie tyrimo dalyviai, kurie turi pakankamai informacijos išsamesnei tiriamojo reiškinio analizei atlikti. Tačiau tyrimo metu išryškëjus konkrečioms kategorijoms, tiriamieji toliau parenkami jau pagal konkrečias teorines dimensijas, kurių skaičių lemia gaunamos informacijos kiekis.

Kadangi konstruojant tiriamają imti laikytasi fenomenologinio tyrimo tradiciju, tiriamieji parinkti savanoriškumo principu. Be to, atliekant fenomenologini tyrimą svarbu, kad tiriamiesiems tyrimo tema būtų reikšminga ne tik socialiniu aspektu, bet ir asmeniškai, t. y. patraukli intelektualiai ir emociškai. Svarbiausias tiriamiesiems taikomas kriterijus - tai būti išgyvenus fenomeną, domètis jo prigimtimi ir prasmemis. Taip pat svarbus ir tarpasmeninis bendravimas bei tyrejo empatija, nes dalyviai tampa tyrejo partneriais. Toks požiūris lèmé, kad daug tiriamuju tyrèjai pažino kaip studentus. Taigi pasirinkta imtis atitiko kokybiniam tyrimui keliamus reikalavimus.

Imties tūri, kokybinio tyrimo metu taikant interviu metoda, sudare 54 Sporto edukologijos bei Sporto technologijų ir turizmo fakultetų I-IV kursų studentai, parinkti pagal anksčiau nurodytus kriterijus.

\section{REZULTATAI}

Analizuojant interviu turini, siekta diagnozuoti esminius tiriamojo fenomeno (identifikacijos su studento vaidmeniu) aspektus, todèl atsakymai i klausimus analizuoti nuosekliai, juos dalijant $i$ analitinius vienetus. Rezultatai gaunami analizuojant teksto turini ir iš jo išskiriant duomenų kategorijas ir subkategorijas. Toks darbo metodas leido interpretuoti teksto turini.

Analizuojant interviu atsakymus, išskirti prasminiai vienetai, o ju kvantifikavimas ir reitingavimas leido išskirti identifikacijos su studento vaidmeniu savybes:

- Gražiausi gyvenimo metai, idomiai ir linksmai leidžiamas laikas, bendravimas su draugais, studentavimas.

- Savarankiškumas, savarankiškai priimami 
1 lentelè. Suvokiamos ir reglamentuotos studentų teisès LKKA

\begin{tabular}{|c|c|}
\hline & \\
\hline $\begin{array}{l}\text { jo nuomone } \\
\text { alygas ir galimybes mokytis } \\
\text { nių } \\
\text { paskaitas } \\
\text { i savo žinias ir gebèjimus, laikyti egzaminus ir } \\
\text { ertintam } \\
\text { ti } \\
\text { ikštojo mokslo diplomą } \\
\text { ir sulaukti pagalbos (pvz., ì studentu atstovybę) } \\
\text { ipendiją } \\
\text { ti nemokant už mokslą }\end{array}$ & $\begin{array}{l}\text { ademijos reguliamino nustatyta } \\
\text { lias studiju programas, pasirinkti } \\
\text { dėstytojai) } \\
\text { gyvendinimo kokybę bei kreiptis } \\
\text { žinių ivertinimo } \\
\text { studijų reguliamino nustatyta } \\
\text { rrmaciją } \\
\text { iūras } \\
\text { e } \\
\text { išrinktiems i ją } \\
\text { visuomenines organizacijas } \\
\text { iisiją dėl savo teisių pažeidimo }\end{array}$ \\
\hline
\end{tabular}

sprendimai, gyvenimas atskirai nuo tèvų, tapimas savo laimės kalviu.

- Mokymasis mokytis, paskaitú lankymas, patirties kaupimas, rezultatų siekimas.

- Naujų žinių igijimas.

- Naujos patirties igijimas bendraujant su mažai pažistamais asmenimis naujoje aplinkoje.

- Laisvès pojūtis dèl susilpnejjusios tėvų kontrolès ir akademinès aplinkos.

- Pasididžiavimas, kad tuščiai nešvaistomas laikas, kad studento vardas vertas pagarbos.

- Profesinè kvalifikacija, pasirengimas būsimam darbui.

- Atsakingumo už savo ateitị, veiksmus, sprendimus ugdymas.

- Bakalauro laipsnio igijimas, intelektinių gebèjimu gilinimas.

- Bendravimas su dėstytojais ir kitais akademinès bendruomenès nariais.

- Plačios mokymosi ir studentiškos veiklos galimybès.

- Sportinė veikla, fizinis aktyvumas, kūno kultūros veikla.

- Studento pažymėjimas, suteikiantis teisę nuolaidoms ir lengvatoms.

Kiekvienas organizacijos narys turi pareigų ir teisiu, o tai, kaip asmuo jas suvokia, kaip jomis vadovaujasi, atskleidžia jo sampratą apie savo atliekamą socialinị vaidmeni organizacijoje. Tyrimo metu studentai išsakè savo teises, kurios pagal svarbą (tiriamiesiems) surašytos 1 lentelèje, o palyginimui pateiktos studentú teisès, numatytos Lietuvos kūno kultūros akademijos statute.

Pažymètina, kad nè vienas apklausos dalyvis nebuvo skaitęs LKKA statuto. Interviu metu studentai vardijo teises, kurias mano turi ir kuriomis teko pasinaudoti. Nemažai studentų išvardytų teisių yra nurodyta LKKA statute, pavyzdžiui, teisè reikšti savo nuomonę, turèti sąlygas studijuoti, teisè i stipendiją. Kai kurios kitos teisès neminimos, nes studentams jos nèra reikšmingos, arba šias teises jie suvokia kaip savaime suprantamus dalykus, pavyzdžiui: teisè laisvai burtis į klubus, draugijas, teisè rinkti studentų atstovybę ir būti išrinktam i ja. Tokia situacija leidžia manyti, kad kai kurių savo teisių studentai nežino, nes nėra skatinami jomis naudotis, pavyzdžiui, teisè studijuoti pagal individualias studiju programas, teisè pasirinkti desstytoją, teisè i studiju programų ir i jų igyvendinimo kokybės vertinima, teisè kreiptis i Akademijos administraciją dèl žinių vertinimo. Minètos teisès orientuotų studentus jaustis pilnateisiais organizacijos nariais, o pačių studentų išvardytos teisès — tik i organizacijos paslaugu vartojima, bet ne i visavertę narystę. Studentams reikšmingos pareigos išvardytos 2 lenteleje.

Kaip matyti iš lentelès duomenų, studentai mano, kad jiems nedera chuliganiškai, šiurkščiai elgtis, keiktis, izžeidinèti dèstytojus, konfliktuoti su jais ir draugais, jiems netinka išduoti draugus, lengvabūdiškai žiūrèti ị mokslą, praleidinèti paskaitas, sukčiauti, nusirašinèti, kenkti akademijos 
2 lentelè. Suvokiamos ir reglamentuotos studentų pareigos LKKA

\begin{tabular}{|c|c|}
\hline LKKA studentu suvokiamos pareigos & LKKA studentu pareigos, numatytos statute \\
\hline $\begin{array}{l}\text { - Mokytis } \\
\text { - Gerbti dėstytojus } \\
\text { - Dorai ir atsakingai elgtis } \\
\text { - Laiku atsiskaityti } \\
\text { - Lankyti paskaitas } \\
\text { - Nenusirašinėti ir nesukčiauti } \\
\text { - Semtis žinių, siekti tobulèti } \\
\text { - Būti geru sportininku } \\
\text { - Atlikti namų darbus, nedaryti gèdos akademijai } \\
\text { - Negadinti inventoriaus } \\
\text { - Stengtis tapti geru specialistu }\end{array}$ & $\begin{array}{l}\text { - Vykdyti studijų programoje nurodytas užduotis } \\
\text { - Laikytis aukštojo mokslo įstatymo, Akademijos statuto, studijų } \\
\text { reguliamino, kitų teisės aktų ir vidaus tvarkos taisyklių } \\
\text { - Vykdyti akademijos savivaldos institucijų sprendimus ir } \\
\text { rektoriaus įsakymus } \\
\text { - Teisès aktų nustatytais atvejais ir tvarka grąžinti suteiktas } \\
\text { paskolas }\end{array}$ \\
\hline
\end{tabular}

vardui, vogti, vartoti alkoholi ir narkotikus, pavydèti draugams pažymių.

\section{REZULTATŲ APTARIMAS}

Tyrimo duomenys rodo, kad studentai įvairiai identifikuojasi su studento vaidmeniu aukštojoje mokykloje. Toki rezultatą pirmiausia lemia būsimujų specialistų identifikacijos su studento vaidmeniu ypatumai, nes, pasak J. A. Dutton ir J. M. Dukerich (1994), konkrečiu gyvenimo etapu asmuo labiausiai identifikuojasi su tokia socialine grupe ar aplinka, kuri jam reikšmingiausia. Kadangi identifikacija su vaidmeniu keičia asmens (šio tyrimo metu - studijuojančio) mąstymą, elgesị ir veiklos motyvaciją (taigi ir pačią veiklą), tai suprantama, kodèl ịvairuoja tirtų asmenų identifikacija su studento vaidmeniu. Pažymėtina, kad nuo to, kaip asmuo suvokia aukštosios universitetinès mokyklos identiteta, priklauso jo identifikacijos su studento vaidmeniu gilumas (Jackson, Dutton, 1988; Kardelis, Karanauskienè, 2003). Galima manyti, kad aukštoji universitetinè mokykla studijuojantiems, o ypač nedirbantiems studiju metais, yra svarbiausia organizacija. Vadinasi, čia vykstanti asmens identifikacija yra aktualiausia ir jo socialiniam identitetui, t. y. asmens identifikacijos su studento vaidmeniu pobūdis vienaip ar kitaip keičia jo elgesị ir veiklą.

Būsimujuc kūno kultūros mokytojų ir sporto šakos trenerių identifikacija su studento vaidmeniu rodo, kaip jie save suvokia aukštojoje universitetinèje mokykloje. Būsimieji specialistai išgyvena teigiamas emocijas dèl mokymosi, formuodami profesinius igūdžius ir kaupdami pedagoginę bei socialinę patirti. Be to, tyrimo dalyviai akcentuoja malonumus, kurie neišvengiami studijų metais tarp akademinio jaunimo. Minètos identifikacijos su studento vaidmeniu apraiškos gali būti ir sè- kmingu studijų, ir atsakingos profesinès veiklos prielaidomis.

Studentai savo vaidmeni dažniau suvokia identifikuodamiesi su būsima profesija, siekiant asmeninio tobulejimo, o ne identifikuodamiesi su studiju vieta, t. y. aukštaja mokykla. Tyrimo dalyviams aukštoji mokykla - tai priemonè norint igyti profesinę kvalifikaciją, tobulinant gebejjimus. Kadangi tirti studentai dažnai elgiasi kaip aukštosios universitetinès mokyklos klientai, tai galima teigti, kad akademinis jaunimas retokai identifikuojasi su aukštaja mokykla, nors čia formuojasi jų savivoka ir realizuojami lūkesčiai. Tokia situacija turètų skatinti aukštosios universitetinès mokyklos bendruomenę, ypač administraciją (rektorata), susimąstyti. Šị teigini paremia kitų tyrèjų rezultatai apie identifikacijos su aukštaja universitetine mokykla ypatumus. Nustatyta sąsaja tarp studento identifikacijos su studijų vieta pobūdžio ir jo mokymosi pasiekimu (Newmann et al., 1992; Steele, 1992). Be to, yra ryšys tarp studento identifikacijos su aukštaja mokykla apibūdinimo ir jo suvokimo apie mokymosi svarbą karjerai (Pintrich, DeGroot, 1990).

Akcentuojama, kad kintant organizacijos aplinkai kinta ir jos identitetas, kartu keičiasi ir organizacijos narių identifikacijos su ja pobūdis. Toks reiškinys leidžia teigti, kad akademinio jaunimo silpną identifikaciją su aukštaja universitetine mokykla lemia nepatenkinti studentu poreikiai studijuojant. Pavyzdžiui, kai akademinis jaunimas išgyvena neigiamas emocijas dèl mokymo (mokymosi) ypatumu ir kai juos liūdina bendradarbiavimas su dèstytojais (Eccles et al., 1993), tai silpnejja jų identifikacija su aukštaja universitetine mokykla.

Tyrimo duomenys apie akademinio jaunimo identifikaciją su tokia studento vaidmens apraiška kaip studentavimas - kai dažniau rūpi pramoginiai studentų renginiai nei mokymasis — rodo, kad formaliu profesinès identifikacijos etapu būsi- 
miesiems specialistams trūksta gilesnio suvokimo tokio studijų motyvo, kaip siekti sèkmès, atliekant Ł̇vairius studentui būdingus veiksmus. Pabrèžtina, kad neformaliu profesinès identifikacijos etapu akademinis jaunimas jiems naujoje bendruomenèje, taigi organizacijos kultūroje, pasirenka vartotojiškos visuomenès ir infantilaus asmens gyvenimo būdą - gèrybiu isigijimą, jų eikvojimą, aplinkos ir žmogaus (grupès) nuolatini gyvenimo stiliaus konstravimą (Vosyliūtè, 2003). Taip teigti leidžia tyrimo rezultatai, gauti apklaustiems asmenims nurodžius tokị teigiamą aspektą kaip laisvès pojūtis dèl susilpnejjusios tẻvų kontrolès.

İomu pastebèti, kad tyrimo dalyviai, lygindami save su tèvais, kai šie studijavo, mano, jog dabar studentai, t. y. jie, yra laisvesni. Apklaustas akademinis jaunimas nurodo, kad šiandien jie paprasčiau žvelgia i pasauli, o svarbiausia - patys sau kelia tikslus. Be to, tyrimo dalyviai iškėlè prieigos prie i̇vairių informacijos šaltinių ir geresnių nei jų tėvų mokymosi aukštojoje mokykloje sąlygu dèl informacinių ir komunikacinių technologiju plètros reikšmę. Kita vertus, akademinis jaunimas teigia, kad turi daugiau pramogu ir teisių nei jų tevvai studijų metais, o ypač reikšminga teisė - studijuoti užsienyje, tačiau jų menkesnès finansinès galimybès, nei buvo jų tèvų; be to, dabar studentams keliami didesni reikalavimai. Tirti asmenys save laiko ne tik drąsesniais, protingesniais, nei jų tėvai buvo aukštojoje mokykloje, bet ir šiurkštesniais, t. y. jie dažnai nèra mandagūs. Tyrimo dalyvių išsa- kyti skirtumai leidžia teigti, kad dabar akademinis jaunimas, identifikuodamasis su aukštaja mokykla, suvokia save dažnai kitaip nei jų tėvų kartos studentai dèl vartotojiškos visuomenès ir liberalumo ugdymo institucijose.

Apibendrinant tyrimo rezultatus formuluotina prielaida, kad aukštojoje universitetinejje mokykloje akademinio jaunimo identifikacija su studento vaidmeniu galètų (ir turètų) būti jų sėkmingu studiju sąlyga.

\section{IŠVADA}

Tyrimo rezultatai leidžia hipotetiškai teigti, kad akademinio jaunimo sèkmingą identifikaciją su studento vaidmeniu lemia tokie mokymosi aplinkos komponentai: 1) komunikacinis, ypač bendradarbiavimas su akademinès bendruomenès nariais, išgyvenant teigiamas emocijas; 2) pragmatinis, ypač studijų organizavimas, derinant studentų poreikius ir studijų programos tikslų realizavima; 3) vertybinis, išskiriant dokumentų apie aukštaji mokslą ir aukštają universitetinę mokyklą analizę, igalinant studijuojantiji vertinti savo, kaip studento, teises ir pareigas, atskleidžiant jam studento, kaip partnerio, privalumus.

Išvardytieji akademinio jaunimo identifikacijos su studento vaidmeniu aspektai lemia ir karjeros ypatumus, ir profesini ịvaizdị, sąlygojantị kūno kultūros bei sporto specialisto prestižą visuomenèje.

\section{LITERATŪRA}

Antinienè, D. (2002). Asmens tautinio tapatumo tapsmas. Sociopsichologinès šio proceso interpretacijos. Sociologija. Mintis ir veiksmas, 2, 100-107.

Burke, P. J. (1991). Identity processes and social stress. American Sociological Review, 56, 836-849.

Burke, P. J., Tully, J. C. (1977). The measurement of role identity. Social Forces, 54 (4), 881-897.

Chen, W. (2003). Evaluation of pre-service teacher preparation for achieving the national standards for beginning physical education teachers. Journal of Personal Evaluation in Education, Dec, 17 (4), 331-347.

Dolby, N. (2004). Encountering an American Self: Study abroad and national identity. Comparative Educational Review, 48 (2), 150-174.

Dutton, J. E., Dukerich, J. M. (1994). Organizational images and member identification. Administrative Science Quarterly, 39 (2), 239-264.

Eccles, J. S., Midgley, C., Wigfed, A. et al. (1993). Development during adolescence: the impact of stageenvironment on adolescents' experiences in schools and families. American Psychology, 48 (2), 90-101.

Jackson, S. E., Dutton, J. E. (1988). Discerning threats and opportunities. Administrative Science Quarterly, 33, $370-387$.

Karanauskienè, D. (2006). Būsimuju kūno kultūros ir sporto specialistu identifikacijos su aukštaja mokykla raiška: daktaro disertacija. Vilnius: VPU.

Karanauskienè, D., Kardelis, K. (2005). The relationship between students' academic identity and their academic achievements. Socialiniai mokslai, 1 (47), 62-70.

Kardeliené, L. (2005). Academic library as the space for the development of future physical education professionals' competence. Socialiniai mokslai, 3 (49), 104-115. Kardelienè, L., Gudzinevičiūte, O. L., Mykolaitienė, L. (2005). Competence of would-be specialists of physical education and sports: Urgent problems of studying language for special purpose. Ugdymas. Küno kultūra. Sportas, 5 (59), 34-41.

Kardelienė, L., Kardelis, K. (2006). Pedagoginè komunikacija kūno kultūros veikloje. Kaunas: LKKA.

Kardelis, K., Karanauskienė, D. (2003). Studentų suvokto aukštosios mokyklos identiteto bei įvaizdžio ir jų veiklos motyvacijos sąsaja. Ugdymas. Küno kultūra. Sportas, 4 (49), $25-30$. 
Malinauskas, R. (2004). Sporto pedagogu socialinès parengties raida. Socialiniai mokslai, 3 (45), 27-33.

Marx, D. M., Brown, J. L., Steele, C. M. (1999). Allport's legacy and the situational press of stereotypes. Journal of Social Issues, 55, 723-743.

Newmann, F. M., Wehlage, G. G., Lamborn, S. D. (1992). The significance of sources of student engagement. In F. M. Newman (Ed.), Student Engagement and Achievement in American Secondary Schools. New York: Teacher College Press.

Osborne, J. N. (1997). Identification with academics and academic success among community college students. Community College Review, 25 (1), 59-69.

Pintrich, P. R., DeGroot, E. V. (1990). Motivation and self-regulated learning components of classroom acade- mic performance. Journal of Educational Psychology, $82,33-40$.

Purdie, N. (2003). Self-Identity and Positive Outcomes of Schooling for Indigenous Australian Students (Paper presented at NZARE AARE). New Zealand, Auckland.

Steele, C. M. (1992). Race and the schooling of AfricanAmerican Americans. The Atlantic Monthly, 6, 68-78.

Steele, C. M. (2003). Through the back door to theory. Psychological Inquiry, 14 (3-4), 314-317.

Strauss, A. L., Corbin, J. (1998). Basics of Qualitative Research: Techniques and Procedures for Developing Grounded Theory. Thousand Oaks: Sage.

Voelk1, K. E. (1997). Identification with school. American Journal of Education, 105, 294-318.

Vosyliūtè, A. (2003). Vartojimas kaip socialinè problema. Filosofija. Sociologija, 3, 41-49.

\title{
WOULD-BE SPECIALIST'S IDENTIFICATION WITH STUDENTS' ROLE AS A PRECONDITION TO PROFESSIONAL CAREER
}

\author{
Diana Karanauskienė, Laimutė Kardelienė, Kęstutis Kardelis \\ Lithuanian Academy of Physical Education, Kaunas, Lithuania
}

\begin{abstract}
The article seeks to analyze how students form their student identity, i. e. how they identify with their students' social role. They were asked what meanings they prescribed to this role, what made the role significant to them. The detailed analysis of role identification would enable us to predict how students are inclined to learn and seek for knowledge. Thus the research object was manifestation of students' role identification, and the research aim was to reveal this identification.

The method of the qualitative research was a semi-structured interview which reflected the main components of role identification. The sample consisted of 54 Ist - IVth year students of the Faculties of Sports Education and Sports Technologies and Tourism who were selected according to the criteria of theoretical sampling. All the participants volunteered in the research.

Students' role identification showed how students perceived their social position at the institution of higher education. Thus, all manifestations of students' role identification can be suppositions of successful studies, independent work and responsible activities. Research revealed that students' role identification was associated not only with their studies but also with their pastime and sports activities. As all manifestations of students' role identification are linked to their studies and sports activities, we can assume that successful role identification at the institution of higher education could be a precondition of their successful studies. Research data allowed us to assume that successful identification with students' role of the academic youth at the institution of higher education is preconditioned by the following components of the learning environment: 1) communicative component, especially communication with the members of academic community, experiencing positive emotions; 2) pragmatic component, especially organization of studies, combining students needs and the realization of the targets of study programs; and 3) value component, emphasizing the analysis of the documents of higher education, which enables students to evaluate their rights and responsibilities and to perceive the advantages of student's position as of social partner. All the aspects of the identification with students' social role of the academic youth, revealed in the research, could have a great impact on the future career peculiarities and professional image influencing the image of a specialist of physical education and sport in our society.
\end{abstract}

Keywords: social identification, students' social role, role identification, institution of higher education.

Gauta 2006 m. rugsèjo 12 d.

Received on September 12, 2006

Priimta 2006 m. gruodžio $6 \mathrm{~d}$.

Accepted on December 6, 2006
Diana Karanauskienè

Lietuvos kūno kultūros akademija

(Lithuanian Academy of Physical Education)

Sporto g. 6, LT-44221 Kaunas

Lietuva (Lithuania)

Tel +370 37302663

E-mail d.karan auskiene@lkka.1t 